\title{
Double Homeobox Protein 4-Like Protein 2
}

National Cancer Institute

\section{Source}

National Cancer Institute. Double Homeobox Protein 4-Like Protein 2. NCI Thesaurus. Code C147933.

Double homeobox protein 4-like protein $2(424 \mathrm{aa}, \sim 45 \mathrm{kDa}$ ) is encoded by the human DUX4L2 gene. This protein may be involved in transcriptional regulation. 